\title{
46,XY Sex Reversal 1
}

National Cancer Institute

\section{Source}

National Cancer Institute. 46,XY Sex Reversal 1. NCI Thesaurus. Code C128188.

Sex reversal in an individual with $46, X Y$ karyotype caused by point mutations or deletions in the SRY gene, encoding sex-determining region Y protein. 